Ивана Јовановић

Самостални истраживач

Крушевац

vasdejks@gmail.com
821.163.41.08-31 Андрић И. https://doi.org/10.18485/ai_lik.2019.5.7.3

Оригинални научни рад

\title{
ВЕРБАТОЛОШКИ И ИСТОРИЈСКО-СОЦИОЛОШКИ \\ АСПЕКТ ПРОУЧАВАҢА ЕТНИКУМА У АНДРИЋЕВИМ ДЕЛИМА
}

У овом раду осветљавамо неке вербатолошке и историјско-социолошке аспекте проучавања етникума у Андрићевом уметничком наративу и утврђујемо да се артифицијелна својства књижевног Андрићева романескног изражавања испољавају у посебном богатству историјских и културолошких мотива и микротема, у нарочитој обојености, експресивности и сликовитости вербатолошких ресурса, и у инвентивности стилских поступака који се огледају, пре свега, у композиционим конструктима изградње етникумских сижеа.

Кључне речи: етникум, наративизација, стилизација, карактеризација, композиција.

\section{1. Уводне напомене}

1. Прозно дело свој смисао не остварује првенствено преко самобитности и сугестивности језика, већ и у језиком испричаној причи. У том смислу, Андрићев прозни тип саопштавања карактеришу не само ширина у развијању животних и историјских слика, и - у семиолошком смислу другостепена објективност приповедања, већ у њега језичка средства и мотивско-идејни склоп као да тек посредовано долазе у своју властиту димензију јер су подешени претежно према спољашњој перспективи и приказивачком моменту (исп: Абот 2009), а опет су уметнички симптом да је Андрић „часно проживео искушења историје” (Делић 2011). 
2. Преузимајући Јакобсонову (1966) мисао да је суштина језичке уметности препознатљива не у структурним својствима књижевног дела (на чему Лотман (1976) инсистира), већ у функционалним, Зденко Лешић (1982: 41) сматра да је језик једног дела заправо природни језик само преоријентисан да врши специјалну службу. Он као пример наводи Андрићев језик у роману Травничка хроника, и каже да се реченице употребљене у овом делу не разликују од неких конструкција у историјском спису ни по структури ни по значењу које имају, јер овај роман говори о историјским чињеницама онако како би о њима могла говорити и историја, биографија или нека слична наука (исп, нпр: Јиричек 1988, Станојевић 2008). Међутим, у контексту романа ове реченице функционишу другачије него што би функционисале у контексту нпр. биографског списа. Њихова функција није да пренесу пуку информацију, већ да креирају један свет имагинације.

3. Лаусберг (1960: 78) наглашава да се писац не бави искључиво језиком већ и духовним наслеђем које представља материјал који он користи да би обликовао једно дело. На питање где је и како похрањено то наслеђе, одговор налазимо код Сапира (1992: 15) да је језик трезор и једини појавни облик те грађе, али и да он има два слоја: слој латентног садржаја и онај други где постоје посебни елементи који утичу на начин како ћемо регистровати то језичко искуство.

а) Природа наратива и вербатолошки карактер Андрићевог романескног опуса сагледиви су као идиосинкрастична целина, али, с друге стране, дозвољавају микрожанровску диференцијацију (исп: Бал 2000, Барт 1975). Узмимо овде за илустрацију два историјска романа, романа хронике - На Дрини ћуйрија и Травничка хроника. Док хроника о Вишеграду и његовим становницима у роману На Дрини ћуйрија представља углавном фикционалну радњу обогаћену усменим легендама, понегде прожету историјским подацима, Травничка хроника се заснива искључиво на историјским подацима. Животи конзула, њихово прилагођавање суровој босанској природи и необичном менталитету њених етника - представљају углавном производ пишчеве имагинације, али сама суштина преузета је из историјских и етнолошких извора. 
б) Особен начин уметничког транспоновања кроз народна предања и легенде провлачи се готово кроз сав Андрићев уметнички наратив, од интимних записа преко медитативне прозе до приповедака и историјских романа. Како истиче Видосава Стојанчевић (1981: 484), „у својим уметничким обликовањима људи и животног простора, Андрић је врло често полазио од неког мита или легенде да би, идући њиховим траговима као 'знаковима и путоказима', залазио дубоко у оне преломне етапе историјских збивања, људских судбина и свих оних животних сукоба којима се формирао менталитет људи балканског простора". На тај начин успостављао је везу између етничке и културне прошлости и садашњости да би што дубље ушао у међуетничке и међурелигијске контакте свих народа ових простора и њихову обичајну традицију.

4. Слика или културни модел света коју ишчитавамо из Андрићева језика и стила ${ }^{1}$ може се одредити као вербатолошка интерпретација света кроз приповедну сегментацију, опис, композиционо уређење, а по правилу, и оцену2 Разматрањем етника кроз горепоменуте стилске поступке упознајемо се са сликама уграђеним у искуство генерација којима Андрић поверава радњу и даје реч, а самим тим сагледавамо свет и прилике у друштву са њиховог аспекта.

\section{2. О етникумима са историјског, социолошког и језичког аспекта у Андрићевом поетском наративу}

1. Период урушавања отоманске империје посебно је обрађен у Травничкој хроници, На Дрини ћуйрија и Омерйаши Лайасу. Историјске догађаје који битно утичу

1 Then a strange blight crept over the area and everything began to change. Some evil spell had settled on the community: mysterious maladies swept the flocks of chickens; the cattle and sheep sickened and died. Every where was a shadow of death." (Karson 1962: 2).

Исп: Станојчић 1967, Пецо 1980, Пецо 1992, Пецо 1993, Живковић 1999, Šamić 2005, Башчаревић 2005.

2 О 'оцени' или 'коментару' у српској књижевности пише Милосављевић-Милић (2006). 
на српско становништво у Босни (уп: Хамер 1979), Андрић је сликовито приказао кроз понашање везира, паша, ага и бегова према босанским Србима за време Првог и Другог српског устанка. Уз то, у Андрићевим је делима имплицитно или експлицитно изражен став Отоманског царства према Босни: за ово је царство, наиме, Босна проблематична периферна територија ове империје, из које се исцрпло све што се могло; у којој је становништво доведено у стање крајње беде и сиромаштва, са перспективом неминовних буна и ратова у циљу биолошког опстанка. Сама додирна линија Босне са Европом и монархијама у узлазној линији просперитета који нуди савремени век, Турцима даје довољан разлог да силом обуздају рају и задрже те територије под својом влашћу. Ово време је несигурно и за главу на раменима - како за рају, тако и за виђеније Турке. То се посебно види из поступака везира који су терор и султанову власт спроводили често и беспотребним и беспримерним крвопролићем међу агама и беговима, као што је описано и у Андрићевим романима.

1.1. Закон терора, па и опште безвредности свачијег живота, посебно хришћанског, пре свега православних Срба, који се физичким уништавањем и исламизацијом ('турчењем') бројно осипају и сабијају на маргину живота и у очај - нарочито је долазио до изражаја када су власт у своје руке узимале аге и бегови у одсуству везира. Терор над Србима у таквим околностима и њихов безнадни положај, Андрић је приказао управо у поменутој Травничкој хроници.

1.2. Период након Берлинског конгреса 1878. године, као и анексије Босне од стране Аустро-Угарске, довели су босанске Турке (у ствари 'Турке', исламизиране Србе) у скоро сличну ситуацију као и осталу рају. Имућнији Турци су напустили Босну, а они који су се ту вековима укоренили, остали су да са осталим становништвом деле наметнуту судбину. Тек под заједничким окупатором неки Турци су осетили солидарност према Србима - што се најбоље види у односу попа Николе и хоџе, двојице ретко хуманих људи, и сл. Но без обзира на овај пример, због вековног угњетавања и терора, Турци и Срби су остали раздељени непремостивим јазом. 
2. Након Руско-турског рата 1877-1878. године, Санстефанским миром (потписан 3. марта 1878. г) Босна је добила неку врсту самосталности у оквиру Отоманске империје, а Берлинским конгресом (13. јуни-13. јули 1878. г) Аустро-Угарска је добила право да ради спречавања продора Русије на Балкан, спроводи власт на територији целе Босне и Херцеговине. У том периоду Срби нису осетили бољитак: једна туђинска власт замењена је другом, однос новог окупатора је мало цивилизованији, али беда и огромна немаштина је и даље остала.

2.1. Оно што је Аустро-Угарска видела као економски потенцијал вредан окупаторског труда, јесу природни ресурси Босне (оно што није интересовало Турке), па је увођењем железнице успела да започне индустријску експлоатацију дрвне грађе. Тако се са индивидуалне пљачке већ опљачканог становништва прешло на пљачку и експлоатацију природних добара под видом индустријализације и модернизације Босне (исп: Мандић 1978). То се најбоље може осетити у Андрићевим описима Вишеграда када је изграђена железница - у роману На Дрини ћуӣрuја.

2.2. Каснији период, укључујући и Први светски рат, непријатељски однос Аустро-Угарске монархије према Србији умногоме се одражавао и на Србе у Босни. Тај се процес између осталог огледа и у језичким приликама, у лексици и синтакси. У роману На Дрини ћуирија, на пример, три пута је више германизама него у Травничкој хронищи, а ову чињеницу управо можемо објаснити тематиком романа. Наиме, док се готово половина романа На Дрини ћуйрија бави аустријском окупацијом Босне, те је акценат стављен на историјске и војне податке, у другом роману у фокусу су приватни животи француског и немачког конзула. Међутим, приметили смо да је број речи и израза преузетих из немачког језика који се појављује у свом изворном облику већи у хроници о конзулским временима. Такође, у овом роману чешће су читаве реченице на немачком језику које се јављају искључиво у говору ликова.

3. Интересантно је у разматрање узети и лик као одредницу етникума, јер је велика галерија ликова у Андрићевом 
приповедном опусу - без обзира да ли су на главној или споредној линији приповедања. Као по правилу, скоро сви имају конкретно име и презиме, имају и до детаља приказану биографију, и редовно - лични опис. Међутим, у палети безбројних ликова, Андрић веома често користи стереотипе, тако да се већина ликова може сместити у клишее који су карактеристични за етникум коме ти ликови припадају (исп: Чатман 1978).

3.1. У роману На Дрини ћуйрија, Црногорац је висок, мршав, у поцепаној и изношеној ношњи, са брковима, лењ је и покушава да побегне од присилног рада на мосту. Но, уз то је и добар гуслар и певач јуначких песама, те управо тако мотивише и подстиче осталу рају на непослушност и пружање отпора Турцима.

a) Италијан, власник путујућег циркуса у приповеци Ћоркан и Швабииа - малог је раста, сув и спечен, док је његова супруга крупна, снажна, и испољава нескривену супериорност и агресивност. Истотипски су приказани и Италијан каменорезац и његова супруга у роману На Дрини ћуйрија. Жена доброћудног Италијана Петра љутито грди свог мужа који не одговара на провокације касабалија, већ долази кући жалостан. Стана му даје савет како да се отараси оних који га прогањају и ругају му се:

- Ти да си мушко, ко што ниси, распалио би га тим длијетом или чекићем по ћиверици, па не би балијама више на ум пало да те задијевају, него би скакали на ноге кад ти прођеш преко ћуприје. (Анрић 19636: 266)

Сваки је локализам стилски маркиран у овој реченици, која је вербатолошки рефлекс негативног расположења према бахатим касабалијским муслиманима.

Узећемо за пример и опис сцене сахране Арапина који је погинуо несрећним случајем приликом изградње моста јер је на њега пао блок који је здробио доњу половину његова тела, па је младић, држећи мајстор Антонијову руку, умро у највећим мукама. Антоније је био потресен због смрти свог сарадника кога је узео да шегртује док је још био дете, па је 
решио да му направи споменик од истог камена од ког се градио мост. Желећи да истакне обичаје при сахрањивању, наратор користи архаизам „нишан” у значењу „знак, белег” (исп: Ћирковић 2006: 110).

Мајстор Антоније му је подигао над гробом леп нишан од камена од ког се мост гради. (Андрић 19636: 66)

б) Србе Андрић углавном приказује као домаћине који у веома тешкој економској ситуацији, у условима турске тираније - често не успевају ни главу на раменима да сачувају. Посебно су безнађем притиснути Срби у роману На Дрини ћyӣpuja: у сценама набијања на колац Радисава са Околишта, уз присилу народа да присуствује бестијалном чину ради застрашивања, или у роману Травничка хроника, у сцени када Цигани муче и убијају двојицу Срба који су оптужени за наводну шпијунажу. У крајње понижавајућим околностима ова два човека трпе иживљавање џелата - и достојанствено, скоро без гласа, у мукама чекају безразложно наметнуту смртну казну. Или када „веселник” Ћоркан - како га наратор назива (у роману На Дрини ћуйрија) - безбрижно пева и игра на огради моста док испод њега хучи моћна Дрина:

У том изузетном и опасном положају, узвишен изнад свих, он није више онај веселник Ћоркан из чаршије и механе... (Андрић 19636: 231)

Поменућемо овде ситуацију у којој препознајемо колико је у сликању српског националног бића Андрићу било стало до религијског момента. Старац Јелисије и младић Миле у једном тренутку схватају да ће их турски војници погубити не толико због преступа који (ни)су учинили колико да би дали пример осталим становницима Вишеграда. Желећи да до краја остане веран својим схватањима, али и да истакне своју православност - старац не могавши да помери везане руке „крсти” речима себе и младића: 
Да се пољубимо и прекрстимо. Во имја Оца и Сина и Свјатаго Духа, Во имја Оца и Сина и Свјатаго Духа. Амин. (Андрић 19636: 98)

в) Цигани (Роми) у Андрићевим су делима углавном без имена и презимена, недостојни детаљног описа јер их не карактеришу позитивне особине. Они су често џелати, и извршавају све прљаве послове за Турке уз адекватну новчану надокнаду. То је посебно наглашено у претходним примерима, када Цигани беспотребно муче Радисава, набијајући га на колац, или браћу, давећи их конопцима, а кад ови изгубе свест, њихово освешћивање врше гребањем лица, чупањем за косу и поливањем водом. А за успешно обављене задатке да човек остане дуже жив на коцу, да се дуже мучи итд. - они наплаћују додатну награду. Колико Андрић према њима има негативан став, види се и по томе да је њихов повлашћени положај насликан заправо као крајња људска беда. Један мали пример тога јесте славље поводом завршетка израде ћуприје на Дрини, које је постало познато и по томе што се Циганче прејело бесплатних колача па је због тога и умрло.

3.2. Турци су најзначајнији етникум помоћу кога Андрић на префињен начин осликава време које је главна инспирација његовог дела. Разликује се опис Турака који долазе по служби у Босну, дакле оних азијатског порекла, од „домаћих Турака" - потурчених Срба, и то: како по лику, тако и по нарави и карактеру. Они први, прави Турци, не цене и не уважавају ове друге, па их често третирају као и осталу рају не презајући да у циљу застрашивања и демонстрације силе одузимају њихове животе и имовину. По томе се посебно истичу везири када у Босну долазе султановим ферманом да заведу „закон и ред”. Андрић у својим делима везире углавном описује у афирмативном облику - уз конверзационе сегменте који су карактеристични за оријенталне мислиоце и њихов начин размишљања (исп: Крагалот 1975).

a) У прологу романа Травничка хроника срећемо, на пример, пословицу чији се смисао понавља и у епилогу и тако заокружује један од идејних слојева романа. Говорећи о доласку нових конзула у Травник, Хамди-бег, један од 
старијих и искуснијих Турака, теши своје млађе сународнике како та ситуација неће бити дугог века.

Ничија није до зоре горила, па неће ни тога... (Андрић 1963д: 12)

Говорећи о Давиловом доласку у прву посету, везир који је упознат са приликама на улицама, где народ гледа странце испод ока, - мрмља кришом и склања се, па каже:

Пас лаје, а караван пролази, завршио је везир, који је очигледно био обавештен о свему што се дешавало за време конзуловог проласка кроз варош и сада настојао да ствар умањи и ублажи. (Андрић 1963д: 39)

б) Често приповедач под наводницима убацује народну изреку, као у Травничкој хрониии - говорећи о страху који је народу из чаршије утерао Али-паша:

Тада су наступила она времена у којима свак настоји да буде мален и невидљив, свак тражи заклона и скровишта, тако да се тада у чаршији говорило да „и мишја рупа вреди хиљаду дуката”. (Андрић 1963д: 475)

А када је реч о дијалогизацији, писац својим ликовима 'ограничава' конверзацију, па тако нпр. у Травничкој хроници не дозвољава догађајима да управљају радњом мимо његових запажања и опсервација. А сама радња - разуме се, уколико је има у делу - мање је у Андрића битна, описана је обично без детаља. Идеално је, пак, у приповедним текстовима са историјском и социјалном темом - описан закон јачег, и терор који су спроводили Турци, како у срединама где је живела раја, тако и међу собом.

3.3. Поред напред наведених у Андрићевом делу појављују се Турци који својим ликом и карактером представљају крајње негативне људе у виду „псета рата” - као што су Мустафа Маџар и Омер-паша Латас. Овај први је манијакални убица који је изгубио разум водећи сурове 
битке како за турски тако и за свој рачун. Овај други је своје војно-стручно знање стечено у Аустријској војној школи због каријеризма уновчио, мењајући веру за вечеру, уз максималну комерцијализацију и маркетинг који у то време за обичну рају није био познат. За разлику од напред поменутих Турака, „домаћи Турци” су задржали карактер етникума свога порекла, које посебно долази до изражаја када су угрожени од правих Турака. Они имају свој начин поимања државе, инсистирају на праву наслеђа предака који су прихватили ислам као своју веру, па су на све друге етничке групе гледали са висине и с ниподаштавањем. У доказивању патриотизма и солидарности према Отоманској империји испољавали су фрустрацију бивше раје, нпр. претерану агресивност према свима осталима, тако да су се у томе заправо посебно разликовали, нпр. по зулуму, од осталих Турака. Tо се најбоље може видети када су вршили власт: сурово је њихово испољавање силе и сурови су злочини које су починили у одсуству везира на територији.

4. Уколико желимо да схватимо суштину карактера као одредницу етникума у Андрићевим делима, морамо сагледати карактер народа који су трпели турску власт у Босни, а егземплар тога јесте положај и начин преживљавања Јевреја. Иако познаје историју Јевреја, Андрић их у својим делима приказује на стереотипан начин, са пренаглашеним шпанским утицајима. Управо чињеница да су Јевреји Сефарди свој последњи егзодус до тада доживели расејањем из Шпаније 1492. године, да су и тамо били Јевреји са својом културом, историјом и традицијом, што их је одржало у њиховој веома дугој историји, не може се осетити мирис шпанске кухиње код Јевреја у Босни након више од 300 година. У Травничкој хроници у кући Јосифа Баруха, где је одсео француски конзул Давил, није се могао осетити мирис Шпаније.

a) Објашњавајући, међутим, сложене међуљудске и дипломатске релације на простору Травника, наратор описује притајене односе аустријског и француског конзула:

Па се онда опет тргну и враћају на посао при догорелим свећама и настављају да пишу своје извештаје у 
којима нема трага малопређашњих осећања и у којима један другог опадају или ниподаштавају, са оне лажне званичне висине са које чиновници мисле да гледају цео свет кад говоре своме министру у поверљивом извештају за који знају да га они на које се односи неће никад читати. (Андрић 1963д: 119)

б) Узгред, већина галицизама у Травничкој хроници припада војној и административној лексици, и готово половина њих сконцентрисана је у седмом поглављу где је описан прво разговор између немачког и француског конзула, а затим и Давилово размишљање о свему што је чуо. Ток мисли немачког конзула који нам наратор детаљно преноси испуњен је позајмљеницама из француског језика како би се постигла веродостојност приповедања. Такође, знатно их је и у седамнаестом поглављу где се говори о последицама Наполеоновог похода на Беч по односе француског и аустријског конзула. Потпуно очекивано галицизми су сконцентрисани у деловима где се говори о француском конзулу Давилу, мада се позајмљенице из француског језика јављају и у језику других личности. Навешћемо пример службеника аустријског конзулата Роте, за кога се каже да је знао десет језика и који у једном разговору жели да се подсмеје Ана Марији и њеној потрази за романтиком из љубавних романа - и то намерно употребљеним вербалним обртом из француског језика (карактеристичним за љубавне романе тог времена):

Рота је већ првог дана рекао у канцеларији, изражавајући се оним поганим језиком којим свет ситних канцеларијских душа говори о онима изнад себе, да „госпођа игра за ангажман”. (Андрић 1963д: 94)

Упркос свим покушајима да га заведе, Рота је остао хладан према супрузи конзула фон Митерера.

б) Вратимо се након овог ексукурса Јеврејима, па ћемо приметити да је њихов детаљни опис - изглед, ношња, амбијент у коме живе и раде, као и начин пословања - у Андрићевим делима у складу са стереотипом који о њима 
влада. Трговина и банкарство су њихова основна делатност: углавном се приказују као вешти трговци и немилосрдни лихвари који нереалном каматом стичу богатства. Међутим, у стварности, Јевреји су етникум без државне заштите, а камате за које им нико не гарантује да ће бити исплаћене многоструко су мање од камата које су наплаћивали хришћани банкари у Европи.

5. Како у настајању естетске слике света у књижевном делу суделују својства свих његових слојева - важно је узети у разматрање етникуме и са језичко-идиоматског аспекта. Уз представљене предметности истовремено се мора запазити и језик којим су оне у Андрићевом уметничком вербативу дочаране.

5.1. Језик као одраз менталитета и културе, како тврди Хајмз (1980: 231), није у Андрића пасивни елемент у сликању њихова међуодноса, већ је ефицијентно средство хармонизације и стилизације наратива. Настојећи да језички именује амбијент Босне, Андрић се није ослањао искључиво на чисто именовање реалија, већ је желео да утиче на интуицију и утисак читалаца користећи експресиво-естетизована језичка средства (уп.: Јаус 1978).

a) Описујући, на пример, Дефосеов први сусрет са босанским стидљивим девојкама наратор каже да му је 'око запело' за једну од њих. Покушавајући да јој се приближи, он jој је у пролазу добацивао по неку реч поздрава коју она није могла разумети, али их је емотивно препознавала:

И младић се насмија и довикну јој неку реч из свог „илирског” речника, ма коју, јер су у тим годинама и у таквим приликама све речи добре и имају значај. (Андрић 1963д: 225)

Јасно да се у овом конктексту лексема „значај” не може заменити лексемом „значење”, а да се не промени значење израза. Наиме, приповедач није желео да истакне да су Дефосеове речи за Јелку имале одређен смисао (што је иначе доминантна сема лексеме „значење”), већ да су оне за њу имале посебну важност (као доминантна сема лексеме 
„значај”). И иначе, Андрић није био љубитељ дијалога. Када је и користио дијалоге они су прво пролазили кроз оно што Асим Пецо назива „властите монолошке пречистаче” (Пецо 1995: 295), тако да је њихова форма најчешће у складу са стандардним језиком.

б) Без сумње можемо тврдити да је Босна са својим становницима и њиховим специфичним културним наслеђем била непресушан извор Андрићеве инспирације. Уз мотиве који су везани за различите крајеве Босне (а посебно Вишеграда и Травника), у романима налазимо и проблематику језика којим говоре ликови, као и сам наратор.

5.2. Андрићев поетизовани историјски или историзирани поетски наратив пружа изобиље података о начину живота и друштвеним приликама у периоду о коме се говори, и кроз њих ми можемо препознати разлике између другачијих менталитета, а те разлике нису ни мале ни ретке. Илустрације ради, у роману Травничка хроника француски конзул износи мишљење (које представља и став самог писца) да на простору, где живе четири вере које засебно знају да је њихов напредак условљен штетом сваке од преостале три, сви се народи труде да задрже своју традицију, начин живота и говора ${ }^{3}$. Идиоматизоване форме - фразеологизми, пословице и друге у обичај узете речи и изрази - на различитом степену контекстуализације присутни су у говору разних етника. Андрић им се вербатолошки радо окреће.

5.3. Већина народних мудрости јавља се непосредно, у дословном и основном облику, било да се налазе у говору приповедача или неког од ликова.

a) У роману На Дрини ћуйрија писац говори о Мухамедбегу као о „човеку који једе царски хлеб”:

Углађен, насмејан, беспрекорно чист и дотеран, шетао је по чаршији, куцкао својом дугом сабљом дискретно по калдрми, и свакоме се јављао љубазно и сигурно, као

3 Говорећи о варијацијама у језичком систему, Радоје Симић каже да избор теме повлачи са собом одлуку да одаберемо и одговарајући начин „вербализације” (Симић 2000: 83). 
човек који једе царски хлеб и нити сумња у себе нити има шта да се прибојава од других. (Андрић 1963б: 260)

У опису ситуације у касаби након аустријске окупације, управо када говори о привидном благостању које је тада владало, Андрић користи израз сличан пређашњем:

То су биле те године привидног благостања и сигурне, па ма и мале зараде, кад су мајке, говорећи о свом сину, додавале: „Да је жив и здрав и да му Бог да лак хљеб!”... (Андрић 19636: 233)

Народни израз срећемо и у сцени где касабалије долазе код газда-Јанка да му честитају на рођењу сина:

- Здрав си, Јанко, - виче један комшија, - да ти је сретан и дуговјечан син; дабогда ти био дика међу домаћинима и један по један у српском уху, у части и чести, у сваком добру и изобиљу. Дабогда... (Андрић 1963б: 354)

б) У Травничкој хроници описује се сусрет великог везира Али-паше са Турцима (који ће бити под његовом надлежношћу), па на томе месту је везиров говор испуњен фразеолошким конструкцијама. Можемо претпоставити да је пашин говор стилски прорачунат на одређену постулирану метафункцију, да звучи, то јест - мудро и искусно како би наметнуо преко потребни ауторитет:

„Ја нисам дошао да се лажемо и кроз камиш љубимо или да спавам на овом шиљтету”, завршио је везир, „него да уведем ред у овој земљи која се до Стамбола прочула по томе што се поноси својим нередом”. (Андрић 1963д: 473)

Сличан је поступак и у опису Давилове жене, где се опет појављује фразеолошка конструкција којом наратор потврђује своју изјаву: 
Једна од оних жена за које у нас кажу „да им се ништа није отело". (Андрић 1963д: 66)

Даље, говорећи о стању у касаби након доласка аустријских трупа Алихоџа у једној од расправа са другим Турцима изражава своје неповерење према њима:

Па зар теби, болан, не долази у памет ово: кад нас за толике крупне ствари, кроз толике године, ни за што не упиташе, откуд сада ова милост од које ребра пуцају? (Андрић 1963б: 339)

Фразеолошка конструкција „милост од које ребра пуцају” ироничан је израз такође постулиране метафункције, оне којом се изражава нечија лажна љубазност.

в) У опису ситуације када су турски војници привели момка Милета који је секао дрва и певао неке од песама које славе српске устанике Андрић говори како је момак збуњен и уплашен и како неспретно покушава да се одбрани, јер није сигуран ни због чега је приведен:

Муцајући и обарајући очи земљи, уверавао је да није ништа певао и да никад није ударао Турцима на образ, да је сиромах, момак у воденици, да је секао дрва и да ни сам не зна зашто је доведен. (Андрић 1963б: 98)

5.4. У роману На Дрини ћуйрија Алихоџа се мирно брани од напада Осман-ефендије, који га назива издајником јер се не жели прикључити борби против „Шваба”:

Нису ми се ни стари крстили па нећу ни ја. Ја, ефендија, нит хоћу са Швабом да се крстим нит са будалом да идем на војску - одговарао је мирно хоџа. (Андрић 19636: 132)

Овде израз „крстити се” значи „десном руком чинити знак крста", а не означава сам чин крштења (исп: РМС 19671976: s.v). 
a) У Травничкој хроници Хамди-бег сумарно и смисаоно упечатљиво вербализује епилог догађања:

- Седам година - каже замишљено и отежући речи Хамди-бег - седам година! А сјећате ли се каква је онда узбуна и повика била због тих конзула и због тога... тога... Бунапарте? Те Бунапарта овђе, те Бунапарта онђе. Те ово ће учинити, те ово неће. Свијет му је тијесан; његовој сили нема мјере ни карара. А овај наш каурлук бијаше дигао главу ко јалов клас. Те једни се држе за скут француском, те други аустријском конзулу, те трећи очекују московског. Лијепо се избезумила раја и повиленила. Па, ево и то би и прође. Дигоше се цареви и саломише Бунапарту. (Андрић 1963д: 532)

б) Преплитање приповедачевог говора са говором једног од ликова срећемо и у роману На Дрини ћуйрија у расправи Осман-ефендије и Алихоџе око доласка Шваба у Босну:

Овај хоџа га је дражио и он му је одговарао са уздржаним гневом, само општим изразима и крупним речима. Иде се куд се мора и са оним са чим се може. Главно је да се душманин не пусти у земљу без боја, а ко много пита, омета ствар и помаже непријатељу. (Андрић 1963б: 129)

Конструкција „са уздржаним гневом” показује ефендијину прикривену мржњу према хоџи и тиме одређује њихов међусобни однос.

7.5. Андрићеве идентификације са ликовима и имитације, посматране са аспекта језичке логике, и посебно са аспекта вербалне идентификације етникума, - чине један од могућих кључева за отварање дубинских и скривенихзначења његова дела. Повремено поистовећивање аутора са наратором, али и са појединим ликовима дела при обраћању читаоцима, значајно је не само при анализи пишчевог стваралачког процеса, већ и у дефинисању односа његовог дела према стварности „као дијалектичко-динамичкој укључености 
човјека у свеколика збивања око себе" (Тутњевић 2013: 192). Уз то, говорећи о честој употреби првог лица у романескном приповедању Иве Андрића, Ронел Александер (1995) повезује ову приповедачеву особину са композиционим истицањем битности саме приче и причања (или са аспекта „непознатог приповедача” - исп: Јерков 2012), јер су „приче које људи причају и препричавају стварније од истина којима се прича бави" (Александер 1995: 202).

\section{3. Закључна опажања}

1. Слојевитост књижевног језика, јасно је, у себи носи и различите језичке јединице и та његова раслојеност је основна претпоставка романескног жанра. Говором аутора, говором ликова, друштвеном и етничком говорном разноликошћу и индивидуалном дисонанцом омогућава се развијање предметно-смисаоног света, а његово разбијање у струје и дијалогизација представљају основне стилске одлике романа (исп: Бахтин 1967: 16), а ти се комуникацијски слојеви не могу проучавати одвојено ${ }^{4}$, ни међусобно, ни од језика. У том смислу, Драгиша Живковић скреће пажњу на распрострањено погрешно веровање да Андрић као сликар Босне у својим делима обилно употребљава босанске локализме ${ }^{5}$ и дијалектизме (Живковић 1999:

4 Или, како Виктор Шкловски запажа (1966: 15): „Уметничко дело стилизује грађу тиме што је обрађује".

5 Како Александар Белић истиче (1998: 189), употреба локализама и дијалекетизама у Андрићевим романима „ствара нарочито добру атмосферу која је потребна па да личности оживе под његовим пером". И Снежана Башчаревић (2005: 94) истиче да се употребом израза из народног говора доприноси истицању карактеристичних особина лица и ствара се јаснија слика њихове класне и професионалне - а ми ћемо додати: и етничке - припадности. Па и сам Иво Андрић каже на једном месту да је реч најбитнији део књижевног стварања, као и да је питање форме књижевног дела и питање језика којим је написано потчињено животној истини (према: Делић 2011). 
197). Не може се оспорити да у његовом делу има доста локалне боје, али се овде мора објаснити да језичких локалитета има само у говору Андрићевих етникума из Босне, и то у мери која тај говор приближава књижевном језику. Андрић посвећује посебну пажњу индивидуализованом вербативу - језику. У Андрићевим романима и приповеткама нема много дијалога, али када се јављају функционално-прагматички су усмерени на реалну карактеризацију босанских сељака, варошана и странаца.

2. Из свега што је речено, може се закључити да је Иво Андрић својим несумњивим приповедачким талентом умео читаоца увести у езотеричан простор и време, у коме се хронолошки тачно и прецизно одигравају историјски догађаји - који детерминишу бит етника периферије Отоманске империје на прелазу средњег у нови век. У својој докторској дисертацији Развој gуховноі животиа у Босни йоg уйииајем тиурске влаgавине (1924), као врстан познавалац историје, филозофије и социологије, - Андрић је на бриљантан и научно емпиријски начин приказао етнике у Босни. Све што је описано у Андрићевим романима и приповеткама, само допуњује комплетну визију Босне тог периода, - а то по себи представља трајно богатство писане речи српског народа и српске историје. Па и подела ликова на битне и случајне у Андрићевом приповедном наративу - нужно измиче овако устаљеној теоријско-интерпретативној визури. Наиме, и они случајно уведени ликови у приповедне догађаје - нису небитни, јер представљају боје помоћу којих Андрић сликарски приказује време, атмосферу и амбијент тренутка о коме пише. Уосталом, у Андрића су приповетке често без конкретне радње, али уз детаљно приказивање споредних ликова. И даље, својеврсним поступком стилске изградње поетске галерије ликова, дакле, њиховом визуелизацијом, Андрић гради слику у складу са жељеним описом карактера, тако да је већина ликова апликативно уведена у дискурзију они су стереотип који се понавља (у виду тематског и стилског варирања) кроз целокупно стваралаштво. 
3. И на крају, етницитет као одлучујућу психосоцијалну категорију у људском унутрашњем и вањском животу, Андрић је умео мајсторски употребити у панорамском сликању света. У тој широкој панорами историје и свакодневног живота уметник гради ненадмашне слике и развија монументалну драму задивљујућег уметничког сјаја.

\section{Извори}

Андрић, Иво. „Јелена, жена које нема”. Сабрана gела Иве Анgрића.

Књ. шеста. Загреб - Сарајево - Београд - Љубљана: Младост Свијетлост - Просвета - Државна заложба Словеније, 1963а. Штампано.

Андрић, Иво. „На Дрини ћуприја”. Сабрана gела Иве Анgрића. Књ. птва. Загреб - Сарајево - Београд - Љубљана: Младост Свијетлост - Просвета - Државна заложба Словеније, 19636. Штампано.

Андрић, Иво. „Немирна година”. Сабрана gела Иве Андрића. Књ. пета. Загреб - Сарајево - Београд - Љубљана: Младост Свијетлост - Просвета - Државна заложба Словеније, 1963в. Штампано.

Андрић, Иво. „Приповетке” ('За логоровања', 'Мустафа Маџар', 'Прича о везировом слону,' 'Бифе Титаник,' 'Аникина времена', 'Мара милосница'). Сабрана gела Иве Анgрића. Књ. прва. Загреб - Сарајево - Београд - Љубљана: Младост - Свијетлост - Просвета - Државна заложба Словеније, 1963г. Штампано. Андрић, Иво. „Травничка хроника”. Сабрана gела Иве Анgрића. Књ. друга. Загреб - Сарајево - Београд - Љубљана: Младост Свијетлост - Просвета - Државна заложба Словеније, 1963д. Штампано.

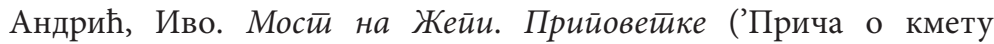
Симану'). Сарајево - Београд: Свјетлост - Просвета, 1967. Штампано.

Андрић, Иво. „Омерпаша Латас”. Сабрана gела Иве Анgрића, Београд: Просвета, 2011. Штампано. 


\section{Извори и литература}

Абот, Портер. Увоg у йеорију йрозе. Београд: Службени гласник, 2009. Штампано.

Alexander, Ronelle. Narrative Voice and Listener's Choice in the Prose of Ivo Andrić. GAIA Research Series. New York: UC Berkeley, 1995. Štampano.

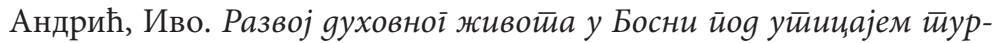
ске влаgавине. Докторска дисертација Иве Андрића, Универзитет Карла Франца у Грацу, 1924. У: Политиика, април 2017. Штампано.

Бал, Мике. Нараӣолоіија. Београд: Народна књига, 2000. Штампано.

Barthes, Roland. „An Introduction to the Structural Analysis of Narrative". New Literary History 6, (1975): 237-272. Štampano.

Бахтин, Михаил. Проблеми йоейике Досииојевскої. Београд: Нолит, 1967. Штампано.

Башчаревић, Снежана. „Основне одлике језика и стила у романима Ива Андрића". Зборник раяова Учитиельскоі факулитетиа Призрен-Лейосавић, (2005): 90-99. Штампано.

Вујаклија, Милан. Лексикон ситраних речи и израза. Београд: Просвета, 1980. Штампано.

Делић, Јован. Иво Анgрић мости и жрйва, Нови Сад и Музеј града Београда: Православна реч, 2011. Штампано.

Durant, Will. „Napoleonovo doba”. Istorija civilizacije. Knj. 12. Beograd: Vojnoizdavački zavod - Narodna knjiga, 2005. Štampano.

Живковић, Драгиша. „Неколико стилских одлика прозе Иве Андрића". Радован Вучковић (прир.). 3борник о Анgрићу. Београд: Српска књижевна задруга, 1999. 182-204. Штампано.

Јакобсон, Роман. Лині̄висииика и йоет̄ика. Београд: Нолит, 1966. Штампано.

Јерков, Александар. „Непознати приповедач Иво Андрић”. С ону стирана Андрића и зла. Ђура Војновић (ур.). РТС, 2012. Веб. 03. 04. 2012. 23:50. www.rts.rs/page/radio/sr/.../aleksandarjerkov-nepoznati-pripovedac-ivo-andric.html.

Јиричек, Константин. Истиорија Срба. Београд: Просвета, 1988. Штампано.

Jaus, Hans Robert. Estetika recepcije. Beograd: Nolit, 1978. Štampano. Kragalott, Jasna. „Turkish loanwords as an element of Ivo Andrićs literary style in Na Drini ćuprija”. Balkanistica. Vol. 2. Columbus, Ohio: Slavica Publishers inc. (1975): 65-82. Štampano. 
Lausberg, Hans. Handbook of Literary rhetoric. A Foundation for Literary study, Brill, 1960. Štampano.

Lešić, Zdenko. Jezik i književno djelo. Sarajevo: Svjetlost, 1982. Štampano.

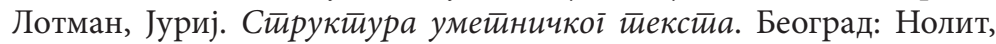
1976. Штампано.

Mandić, Dominik. Državna i vjerska povjest srednjovekovne Bosne. Chicago - Rim: Ziral, 1978. Štampano.

Милосављевић-Милић, Снежана. Моgели коменитара у сритском роману ХІХ века. Ниш: Просвета, 2006.

Peco, Asim. „O nekim specifičnostima Andrićeve rečenice”. M. Popadić (ur.). Travnik i djelo Ive Andrića. Sarajevo: IRO „Veselin Masleša”, 1980. 299-312. Štampano.

Пецо, Асим. „Један поглед на турцизме у писаној ријечи Иве Андрића". Иво Андрић у своме времену 1. Београд: Међународни славистички центар, 1992. 173-181. Штампано.

Пецо, Асим. „Слика босанских говора у романима Иве Андрића”. Јужнословенски филолої, 49. (1993): 95-110. Штампано.

Пецо, Асим. Писии и ғихов језик. Београд: Просвета, 1995. Штампано.

РМС. Речник срйскохрвайскоі̄ книжевной језика. Нови Сад-Београд: Матица српска, 1967-1976. Штампано.

Sapir, Edvard. Jezik. Novi Sad: Dnevnik, 1992. Штампано.

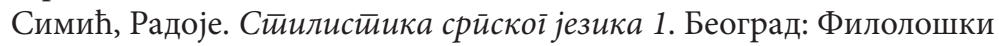
факултет и ЈАСЕН, 2000.

Станојевић, Станоје. Истиорија срӣскої нароgа. Београд: Логос Арт, 2008. Штампано.

Стојанчевић, Видосава. „Етнички проблеми и народна предања у делима Иве Андрића". Драган Недељковић (ур.). Дело Ива

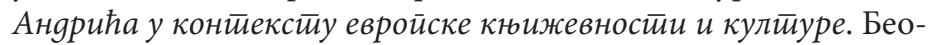
град: Задужбина Иве Андрића, 1981. 483-494. Штампано.

Станојчић, Живојин. Језик и стиил Ива Анgрића. Монографије, књ. XI, Београд: Филолошки факултет, 1967. Штампано.

Тутњевић, Станиша. Босански књижевни тонаи. Развој и конйину-

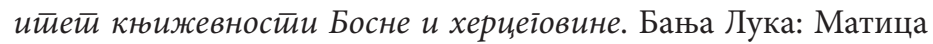
српска, 2013. Штампано.

Ћирковић, Симо. Речник архаизама (или речи изобичајене у срйском језику). Београд: Народна књига, 2006. Штампано.

Ћоровић, Владимир. Истиорија Срба. Београд: Просвета, 2009. Штампано.

Chatman, Seymour. „Characters and Narrators: Filter, Center, Slant, and Interest-Focus". Poetics Today 7.2 (1978): 189-204. Штампано. 
Хајмз, Дел. Еӣноїрафија комуникације. Београд: БИГЗ, 1980. Штампано.

Hammer, Joseph Von. Historija turskog osmanskog carstva I, II i III. Zagreb: Nerkez Smailagić, 1979. Štampano.

Шкловски, Виктор Борисович. „О уметности као мишљењу сликама”. Поља 12. Год. 12, бр. 93 (мај 1966): 12-21.

\title{
Ivana Jovanović
}

\section{VERBATOLOGICAL AND HISTORICAL-SOCIOLOGICAL ASPECT OF THE STUDY OF THE ETHNIC IN ANDRIĆ'S NOVELS}

\begin{abstract}
In this study motives panoramic and methodological frontally, outline the historical, cultural, religious and social frameworks for understanding the Andrić verbativa - in whose thematic focus placed ethnicities. This methodological procedure opens the possibility for recognition of the re-registration of the concept of knowledge in composing Andrićs poetic narrative primarily historical, but also the general social and cultural. The whole object and material layer Andrićs short stories and novels incorporated historical fact-oriented, but she suffered not only stylish translocation, but also higher levels of stylization - trans contextualization and trans codification.
\end{abstract}

Key Words: ethnic group, narratives, stylisation, characterization and composition. 